\title{
The Relationship Between Nurse Job Satisfaction and Turnover Intention: A Private Hospital Case Study in Bali, Indonesia
}

\author{
Ni Made Umi Kartika Dewi ${ }^{1, *}$, Pande Putu Januraga ${ }^{2}$, Ketut Suarjana ${ }^{2}$ \\ ${ }^{1}$ Health Information Management Health Science, Institute of Medika Persada Bali Denpasar, Indonesia \\ ${ }^{2}$ Faculty of Public Health, Udayana University, Denpasar, Indonesia \\ "Corresponding author. Email: nimadeumikartikadewi@ gmail.com
}

\begin{abstract}
One of the health workers needed to provide health services is a nurse. "X" Hospital is a private hospital in Bali which has a nurses turnover rate exceeding the standard limit in the last 5 years, reaching $20.61 \%$ per year thereby reducing the quality of nursing services and overall quality of the hospital. This research is a cross sectional study that aims to determine nurse turnover intentions and explore the relationship between the five dimensions of job satisfaction and nurse turnover intentions. Data were analyzed by univariate, bivariate and multivariate methods. The results of this study were $55.79 \%$ of nurses had turnover intentions and $57 \%$ of nurses agreed that they would look for another job next year if the conditions at the hospital were increasingly not to their liking. Turnover intentions are related to salary satisfaction (AOR: 2.00, 95\% CI: 1.25-3.18) and promotion satisfaction (AOR: 2.03; 95\% CI: 1.40-2.94). The conclusion of this study is that most nurses have the intention to move, so hospital management needs to re-evaluate the salary and incentive system. Promotion needs to be given fairly and equitably, as well as creating training and education programs to improve the career path of nurses.
\end{abstract}

Keywords: job satisfaction, nurse, promotion, salary, turnover intention

\section{INTRODUCTION}

Nurses make up the majority of human resources in hospitals, that is between $60-70 \%$, therefore nurses contribute greatly to the quality of services in hospitals[1]. In Indonesian high turnover often occurs in nurses who work in private hospitals. Surveys conducted in several regions in Indonesia, showed the turnover rate in nurses ranged from $20-35 \%$. Research in three private hospitals in Medan showed a turnover of $34.88 \%, 26.19 \%$ and $24.60 \%$ per year [2], while in Jakarta 21\% [3], and 27.3\% [4], in West Sumatra at 24.3\% [1] and in Malang at 32\% [5]. This figure is far above the standard tolerated turnover rate of nurses- starting at 5-10\% per year [6]. A high turnover rate can cause cost losses including costs required for recruitment and training costs [7]. In addition, high turnover events can also affect nurse morale and result in a decrease in nurses' ability to meet patient needs and provide quality care[8].

Turnover intention is the initial sign of turnover [9]. According to Petronila[10] turnover intention is the intention of the employee to quit his job voluntarily and is the employee's last choice if the work conditions are not in accordance with their wishes. Intention turnover is influenced by many factors, but several studies show that job satisfaction has the greatest influence on turnover intention [11]. Job satisfaction is a feeling that employees feel about their work based on employee ratings on aspects of their work [12]. Job satisfaction consists of five dimensions of satisfaction, namely salary satisfaction, promotion satisfaction, satisfaction with superiors, satisfaction with coworkers and satisfaction with the job itself [13].

Research on nurse turnover intention has been widely conducted in countries other than Indonesia, and the results show that nurse turnover intention is higher in developing countries than in developed countries. A crosssectional study in Lebanon found that as many as $67.5 \%$ of nurses had the intention to leave their jobs [14]. In contrast, a survey by the American Organization of Nurse Executives in 2000 showed that the interest in nurse turnover intention was only $21.3 \%$ [15]. In Indonesia, a similar study conducted at a private hospital in Batam Indonesian, showed nurses turnover intention was around $23 \%$ in 2006 [16] and these results were far lower than the results of a study conducted at a private hospital in Bali that showed nurses turnover intention as much as $42.7 \%$ [17]. Several studies conducted in Indonesia have also linked job satisfaction with turnover intention, but the results are inconsistent. There are results of research that revealed that job satisfaction has a relationship with turnover intention [6], but there are also studies that say that turnover intention does not have a relationship with job satisfaction [1]. 
"X" Private Hospital in Bali was established since 2012. This hospital's Human Resource Department data shows that the number of employee turnovers is getting higher every year. The average turnover of nurses in this hospital in 2013 reached $15.2 \%$, in 2014 it reached $20.61 \%$, in 2015 it reached $18.78 \%$ and in 2016 it reached $20.78 \%$. Interviews with HRD, showed the results of evaluating staff nurses who resigned with the highest reason being wanting to continue their education, increase their career path, care for children and return to their home town. On the other hand, HRD also knows that the real reason for nurses for resigning because they choose to work in public hospitals

\section{METHOD}

"X" Private Hospital is a type B hospital located in Badung Regency. The hospital has 9 treatment rooms: emergency room, child care, inpatient care (I, II, III), lab / HD / Endoscopy room, ICU / HCU / NICU room, outpatient room and operating room. The hospital also has 126 general practitioners and specialists. In addition, there were 167 nurses consisting of 14 structural nurses responsible for nursing management, and 153 functional nurses who were responsible for providing direct nursing services to patients in nine treatment rooms.

The cross-sectional survey was conducted at X Hospital in 2017. The sample size was obtained based on the simple random sampling formula, 95 of 153 functional nurses, randomly selected from the nurse's schedule in each treatment room. Data on nurse demographic characteristics and job satisfaction dimensions were collected in June 2017 by interview. In addition, in order to collect turnover intention data, we provided a questionnaire to be filled out by the respondents themselves.

The questionnaire in this study consisted of 3 sections (A, B and C). Questionnaire A contains questions about nurses' demographic characteristics including age, sex, education, marital status, employment status and years of service. Questionnaire B is a job satisfaction questionnaire adopted from the development of a job satisfaction survey [18]. Total statements from 20 statements consisting of statements of satisfaction with salary (4), satisfaction with promotion opportunities from the hospital (4), satisfaction with coworkers (4), satisfaction with superiors (4) and satisfaction with the work itself (4). Questionnaires used the Likert scale 1-6 for positive statements: the answer "strongly disagree" is allocated a score of 1 , the answer "disagree" is allocated a score of 2, the answer "mildly disagree" is allocated a score of 3, the answer "agree" is allocated a score of 4, the answer "mildly agree" is allocated a score of 5, and the answer "strongly agree" is allocated a score of 6 . As for negative statements, the opposite scoring system is applied wherein the answer "strongly disagree" is allocated the highest score (6), and so on until the lowest score (1) which is allocated for the answer "strongly agree". Questionnaire C is a turnover intention questionnaire consisting of four statements with a likert scale 1-4. "Strongly disagree" (STS) answers are allocated the smallest score (1), and so on until "strongly and other private hospitals. Interviews with 8 nurses who resigned, indicate that they want to find a job with a higher salary, are not comfortable with irregular working hours, feel burnt out, and do not feel developed in the career path. The results of this communication indicate that nurses are less than satisfied with their work. It is therefore necessary to evaluate the level of turnover intention rate of nurses in the hospital and whether the incident is related to salary satisfaction, promotion satisfaction, satisfaction with coworkers, satisfaction with superiors, or satisfaction with the work itself.

agrees" (SS) answers which are allocated the highest score (4). The greater the score obtained indicates the higher the intention of the respondent to leave their job. The answer score of each item in the turnover intention questionnaire statement is summed up and a normal distribution value determined ( $\mathrm{p}$ value $=0.287$ ), so that the cut of point taken is the average value of 10.72 . Then the data is sorted into the respondent group wishing to quit $(\geq 10.72)$ and those do not want to quit $(<10.72)$.

Data were analyzed by univariate, bivariate, and multivariate analysis. Bivariate analysis using chi square to test the characteristics of variables and logistic regression for job satisfaction dimension variables was conducted. Multivariate analysis was performed using binary logistic regression. This research has obtained Ethics Clearance from the Medical Ethics Committee of the General Hospital of Udayana Sanglah University in number: 2017.02.1.0435 on May 8, 2017. Researchers provided information sheets, consent forms and information on the obligations of respondents before they participated in the study. Participants' participation was voluntary, there was no pressure and was anonymous.

\section{RESULTS AND DISCUSSION}

Most respondents were less than 26 years of age, $73.68 \%$ of women, $65.26 \%$ are unmarried and $57.89 \%$ had a diploma in nursing education. $53.68 \%$ of respondents had a working period of time of 3 years with $96.84 \%$ holding permanent employee status. As many as $55.79 \%$ of respondents indicated turnover intention from the hospital. Table 1 presents the details of the percentage of each turnover intention component and job satisfaction. 
Table 1. Distribution of Turnover Intention and Job Satisfaction

\begin{tabular}{|c|c|c|c|c|c|c|c|}
\hline \multirow{2}{*}{\multicolumn{3}{|c|}{$\begin{array}{|ll|}\text { Tumover } & \text { Intention } \\
\text { Components } & \\
\end{array}$}} & 1 & 2 & 3 & 4 & \multirow{2}{*}{ Rate } \\
\hline & & & $\%$ & $\%$ & $\%$ & $\%$ & \\
\hline \multicolumn{3}{|c|}{$\begin{array}{l}\text { Often thinking about finding } \\
\text { job information elsewhere }\end{array}$} & 9 & 30 & 56 & 5 & 2.56 \\
\hline \multicolumn{3}{|c|}{$\begin{array}{l}\text { Looking for work elsewhere } \\
\text { next year }\end{array}$} & 4 & 42 & 45 & 9 & 2.57 \\
\hline \multicolumn{3}{|c|}{$\begin{array}{l}\text { Would find a job elsewhere if } \\
\text { work conditions became } \\
\text { increasingly unfawourable }\end{array}$} & 2 & 20 & 57 & 21 & 2.96 \\
\hline \multicolumn{3}{|c|}{$\begin{array}{l}\text { Often thinking of quitting } \\
\text { their current iob }\end{array}$} & 6 & 37 & 46 & 11 & 2.61 \\
\hline \multirow{2}{*}{$\begin{array}{l}\text { Sub-component } \\
\text { of Job } \\
\text { Satisfaction }\end{array}$} & 1 & 2 & 3 & 4 & 5 & 6 & \multirow[b]{2}{*}{ Rate } \\
\hline & $\%$ & $\%$ & $\%$ & $\%$ & $\%$ & $\%$ & \\
\hline \multicolumn{8}{|c|}{ Satisfaction with salary } \\
\hline $\begin{array}{l}\text { Get paid enough } \\
\text { for the work } \\
\text { done }\end{array}$ & 31 & $\frac{1}{7}$ & 35 & 10 & 7 & - & 2.47 \\
\hline Pay rise too low & - & - & 1 & 11 & 2 & 86 & 5.73 \\
\hline $\begin{array}{l}\text { Feeling } \\
\text { unappreciated } \\
\text { by the } \\
\text { organization }\end{array}$ & 1 & 7 & 7 & 23 & 31 & 31 & 4.66 \\
\hline $\begin{array}{l}\text { Satisfied with } \\
\text { the chances of a } \\
\text { raise }\end{array}$ & 11 & $\begin{array}{l}3 \\
9\end{array}$ & 33 & 12 & 4 & 1 & 2.61 \\
\hline \multicolumn{8}{|c|}{ Promotional satisfaction } \\
\hline $\begin{array}{l}\text { Few promotion } \\
\text { opportunities }\end{array}$ & 4 & 5 & 15 & 33 & 23 & 20 & 4.25 \\
\hline $\begin{array}{l}\text { Fair promotional } \\
\text { ogportunities }\end{array}$ & 2 & 36 & 41 & 19 & 2 & - & 2.83 \\
\hline $\begin{array}{l}\text { Standard } \\
\text { opportunities }\end{array}$ & 2 & 18 & 35 & 21 & 11 & 13 & 3.60 \\
\hline $\begin{array}{l}\text { Satisfied with } \\
\text { promotional } \\
\text { ogportumities }\end{array}$ & - & 37 & 36 & 19 & 7 & 1 & 3.01 \\
\hline \multicolumn{8}{|c|}{ Satisfaction with co-workers } \\
\hline $\begin{array}{l}\text { Happy with co- } \\
\text { workers }\end{array}$ & - & 3 & 1 & 8 & 24 & 64 & 5.45 \\
\hline $\begin{array}{l}\text { Muast work } \\
\text { harder }\end{array}$ & 15 & 20 & 18 & 23 & 22 & 2 & 3.24 \\
\hline $\begin{array}{l}\text { Relatively } \\
\text { commfortable } \\
\text { with their } \\
\text { coworkers } \\
\end{array}$ & - & 4 & 3 & 9 & 42 & 42 & 5.14 \\
\hline Too many fights & 23 & 20 & 22 & 23 & 8 & 4 & 2.84 \\
\hline \multicolumn{8}{|c|}{ Satisfaction with superiors } \\
\hline $\begin{array}{l}\text { The boss is } \\
\text { competent } \\
\text { enough to do the } \\
\text { job }\end{array}$ & - & 2 & - & 25 & 51 & 22 & 4.9 \\
\hline $\begin{array}{l}\text { The boss is not } \\
\text { fair }\end{array}$ & 32 & 27 & 18 & 17 & 2 & 4 & 2.43 \\
\hline $\begin{array}{l}\text { The boss does } \\
\text { not care }\end{array}$ & 34 & 24 & 20 & 18 & 3 & 1 & 2.35 \\
\hline The boss is great & - & - & 9 & 33 & 41 & 17 & 4.65 \\
\hline \multicolumn{8}{|c|}{ Satisfaction with the work itself } \\
\hline $\begin{array}{l}\text { Feels their work } \\
\text { is meaningless }\end{array}$ & 34 & 22 & 20 & 15 & 8 & 1 & 2.45 \\
\hline Likes the job & 8 & 5 & 3 & 11 & 50 & 23 & 4.56 \\
\hline $\begin{array}{l}\text { Proud to do this } \\
\text { job }\end{array}$ & 7 & 2 & 10 & 14 & 45 & 22 & 4.53 \\
\hline $\begin{array}{l}\text { This work is } \\
\text { very fim }\end{array}$ & 7 & 1 & 9 & 16 & 46 & 21 & 4.55 \\
\hline
\end{tabular}

In Table 1 the details of the turnover intention component indicate that the predominant reason for respondents wanting to find work elsewhere would be if working conditions become increasingly unfavorable. Almost evenly, at least half of the respondents seek information about work elsewhere, have the desire to find work elsewhere next year, and even often think of quitting their current job. In the satisfaction component, it is evident that respondents showed less satisfaction with the salary and promotion they obtained. However, respondents are sufficiently satisfied with their co- workers, superiors and their current work. Details of each sub-component are presented in Table 1.

Table 2. Relationship Individual Characteristics and Job Satisfaction with Turnover Intention

\begin{tabular}{|c|c|c|c|c|c|c|c|c|}
\hline \multirow{3}{*}{ Variables } & \multicolumn{4}{|c|}{ Turnover Intention } & \multirow{3}{*}{$\begin{array}{l}P \\
\text { valu } \\
\mathrm{e}\end{array}$} & \multirow{3}{*}{$\begin{array}{l}\mathrm{AO} \\
\mathrm{R}\end{array}$} & \multirow{2}{*}{\multicolumn{2}{|c|}{$\begin{array}{l}95 \% \\
\text { Confident } \\
\text { Interval }\end{array}$}} \\
\hline & \multicolumn{2}{|c|}{$\begin{array}{l}\text { Do not want } \\
\text { to resign }\end{array}$} & \multicolumn{2}{|c|}{$\begin{array}{l}\text { Want } \\
\text { resign }\end{array}$} & & & & \\
\hline & $\mathrm{N}$ & $\%$ & $\mathrm{~N}$ & $\%$ & & & & \\
\hline \multicolumn{9}{|c|}{ Characteristics } \\
\hline \multicolumn{9}{|l|}{ Age } \\
\hline $\begin{array}{l}<26 \text { years } \\
\text { old }\end{array}$ & 28 & $\begin{array}{l}54 . \\
9\end{array}$ & 23 & 45.1 & $\begin{array}{l}0.02 \\
4\end{array}$ & & & \\
\hline $\begin{array}{l}\geq 26 \text { years } \\
\text { old }\end{array}$ & 14 & $\begin{array}{l}31 . \\
8\end{array}$ & 30 & 68.2 & & & & \\
\hline \multicolumn{9}{|l|}{ Gender } \\
\hline Male & 8 & $\begin{array}{l}32 . \\
0\end{array}$ & 17 & 68.0 & $\begin{array}{l}0.15 \\
2 \\
\end{array}$ & & & \\
\hline Female & 34 & $\begin{array}{l}48 . \\
6 \\
\end{array}$ & 36 & 51.4 & & & & \\
\hline \multicolumn{9}{|l|}{ Education } \\
\hline $\begin{array}{l}\text { Diploma } \\
\text { in Nursing }\end{array}$ & 27 & $\begin{array}{l}49 . \\
1\end{array}$ & 28 & 50.9 & $\begin{array}{l}0.26 \\
1\end{array}$ & & & \\
\hline $\begin{array}{l}\text { Bachelor } \\
\text { in Nursing }\end{array}$ & 15 & $\begin{array}{l}37 . \\
5\end{array}$ & 25 & 62.5 & & & & \\
\hline \multicolumn{9}{|l|}{ Status } \\
\hline Single & 27 & $\begin{array}{l}43 . \\
5 \\
\end{array}$ & 35 & 56.4 & $\begin{array}{l}0.85 \\
9\end{array}$ & & & \\
\hline Married & 15 & $\begin{array}{l}45 \\
4\end{array}$ & 18 & 54.5 & & & & \\
\hline \multicolumn{9}{|c|}{ Years of service } \\
\hline$<3$ years & 10 & $\begin{array}{l}22 . \\
7\end{array}$ & 34 & 77.3 & $\begin{array}{l}<0.0 \\
01\end{array}$ & & & \\
\hline$\geq 3$ years & 32 & $\begin{array}{l}62 . \\
7\end{array}$ & 19 & 37.2 & & & & \\
\hline \multicolumn{9}{|c|}{ Employment status } \\
\hline Contract & 1 & $\begin{array}{l}33 . \\
4 \\
\end{array}$ & 2 & 66.7 & $\begin{array}{l}0.58 \\
7 \\
\end{array}$ & & & \\
\hline $\begin{array}{l}\text { Permanen } \\
t\end{array}$ & 41 & $\begin{array}{l}44 . \\
6 \\
\end{array}$ & 51 & & & & & \\
\hline \multicolumn{9}{|c|}{ Level of satisfaction } \\
\hline $\begin{array}{l}\text { satisfactio } \\
\text { n with } \\
\text { salary }\end{array}$ & 14.5 & $\begin{array}{l}1.5 \\
9\end{array}$ & ${ }_{3}^{16 .}$ & $\begin{array}{l}1.4 \\
5\end{array}$ & $\begin{array}{l}<0.0 \\
01\end{array}$ & $\begin{array}{l}2.00 \\
3\end{array}$ & $\begin{array}{l}1.2 \\
5\end{array}$ & $\begin{array}{l}3.1 \\
8\end{array}$ \\
\hline $\begin{array}{l}\text { promotion } \\
\text { al } \\
\text { satisfactio } \\
\text { n }\end{array}$ & 12.3 & $\begin{array}{l}1.4 \\
7\end{array}$ & $\frac{14 .}{7}$ & $\begin{array}{l}1.8 \\
5\end{array}$ & $\begin{array}{l}<0.0 \\
01\end{array}$ & $\begin{array}{l}2.03 \\
5\end{array}$ & $\begin{array}{l}1.4 \\
0\end{array}$ & $\begin{array}{l}2.9 \\
4\end{array}$ \\
\hline $\begin{array}{l}\text { satisfactio } \\
\text { n with co- } \\
\text { workers }\end{array}$ & 17.1 & $\begin{array}{l}3.0 \\
0\end{array}$ & 36. & $\begin{array}{l}3.2 \\
8\end{array}$ & $\begin{array}{l}0.20 \\
3\end{array}$ & & & \\
\hline $\begin{array}{l}\text { satisfactio } \\
\text { n with } \\
\text { superiors }\end{array}$ & 14.3 & $\begin{array}{l}2.3 \\
9\end{array}$ & $\begin{array}{l}14 . \\
4\end{array}$ & $\begin{array}{l}2.9 \\
6\end{array}$ & $\begin{array}{l}0.78 \\
3\end{array}$ & & & \\
\hline $\begin{array}{l}\text { satisfactio } \\
\mathrm{n} \text { with the } \\
\text { work itself }\end{array}$ & 16.4 & $\begin{array}{l}3.5 \\
4\end{array}$ & $\frac{15 .}{9}$ & $\begin{array}{l}4.6 \\
3\end{array}$ & $\begin{array}{l}0.54 \\
4\end{array}$ & & & \\
\hline
\end{tabular}

Description: * characteristic variable tested using chi square, job satisfaction dimension tested by logistic regression, multivariate analysis with binary logistic regression test.

In Table 2, it is evident that there is a relationship between the variable of turnover intention of nurses with several variables of individual characteristics and job satisfaction. Statistically significant individual characteristic variables related to turnover intention are age variables $(p=0.024)$ and years of work $(\mathrm{p}<0.001)$, while the variables related to job 
satisfaction statistically associated with turnover intention are salary satisfaction $\quad(p<0.001)$ and promotion satisfaction $(\mathrm{p}<0.001)$. Variables with $\mathrm{p}$ values $<0.25$ are included in the multivariate analysis model of binary logistic regression and the results are also presented in the table above. The variables independently related to turnover intention were salary satisfaction $(\mathrm{AOR}=2.003,95 \% \mathrm{CI}$ : 1.25-3.18) and satisfaction with promotion $(\mathrm{AOR}=2.035$, 95\% CI: 1.40-2.94).

Published research about the relationship between job satisfaction and turnover intention of nurses is lacking. In Bali, research on nurse turnover was previously conducted at Bali Medika Hospital but this study was not related to job satisfaction. Hospital turnover intention research at "X" hospital indicated that the majority $(55.79 \%)$ of nurses intended to quit their jobs this was related to two aspects of job satisfaction namely salary satisfaction and promotion satisfaction. The results of interviews with questionnaires found that most nurses were not satisfied with the salary and promotion they received at this time. This study also shows that a high percentage of nurses often seek employment information from other places, intend to find other jobs and want to quit this hospital. This is in line with the theory that turnover intentions based on dissatisfaction will lead to thoughts of leaving work marked by often seeking employment information elsewhere. Furthermore, if outside the hospital where they work now offers better opportunities, nurses will be encouraged to move [19].

Salary has a very important role in turnover intention even in advanced countries such as Canada, showing research on salary satisfaction has a direct influence on nurse turnover intention [20]. The results of our study indicate that satisfaction with salary is associated with high nurse turnover intention. The results show that $86 \%$ of respondents strongly agree that the salary increase in their place of work is currently too low. Regular salary increases for employees would impact positively on job satisfaction [21]. Satisfaction with salary indicators on salary increases will result in lower employee desire to consider leaving their jobs [22]. Payroll conditions at X Hospital align with the Republic of Indonesia Minister of Manpower and Transmigration Regulation Number 7 of 2013 concerning Minimum Wages. In this context, nurses have been given basic salary in accordance with the minimum wage regulations in Badung Regency and according to their level of education. In this case all nurses are given a salary not based on their performance but on the current regulation. The hospital also does not provide incentives even though the nurse works hard. The hospital only provides transportation costs beyond the basic salary and a year-end bonus.

In addition to satisfaction with salaries, promotion satisfaction at X Hospital also has a significant relationship with nurse variable turnover intention. Published research about this is absent and research into this needs to be further carried out. In this study respondents demonstrated various opinions on aspects of promotion satisfaction, statements about fairness and promotion opportunities which are evidently the dominant issues related to satisfaction regarding nursing promotion at Hospital $\mathrm{X}$. Based on the results of the study it is evident that some groups of respondents still consider the opportunity of promotion they receive inappropriate with their expectations. The wider promotion opportunities provided by hospitals to nurses will further increase the job satisfaction and vice versa [23]. At present the hospital has classified nurses' career paths in accordance with the Ministry of Health of the Republic of Indonesia in 2006 which set the clinical career path of professional nurses to five levels. This grouping is based on formal education background, work period and a competency test. To improve the career path of professional nurses, formal education background is not enough, each nurse must attend a continuous professional development training program that is routinely conducted by the hospital according to their career level [24].

"X" Hospital does not yet have a specific strategy for providing promotional opportunities for its employees. Candidates for promotions are submitted directly by the head of nursing, however opportunities for promotion should be based on merit not "subjectivity" of people who have the authority to promote others, and the provision of promotional opportunities should apply two criteria namely performance and seniority [25]. The results of this study showed that most nurses had the desire to leave Hospital X, and this was associated with a lack of nurse satisfaction with salaries and promotions provided. This is a challenge for hospital management. Hospital management needs to monitor the adequacy of salaries that are adjusted to the market in general. In addition, regular salary increases and other benefits such as nursing services or incentives may be needed to improve nurse job satisfaction. In relation to promotion, hospital management needs to provide promotion widely and fairly, especially by providing continuing education such as training held both inside and outside the hospital, as well as ongoing academic education. Limitations within this study include the fact that the questions tended to be sensitive and touched on topics such as salaries, promotions, superiors and coworkers so that on average the participants potentially provided neutral responses not necessarily reflecting their actual opinions.

\section{CONCLUSION}

Nurses' high turnover intention rate of $55.79 \%$ indicates that nurses have the desire to leave X Hospital. There are two dimensions of job satisfaction that are significantly related to turnover intention, namely salary satisfaction and promotion satisfaction. Future research should explore more deeply the reasons for turnover intention by using qualitative research methods and linking factors outside the hospital more broadly.

\section{ACKNOWLEDGMENT}

Thank you for the support dr. Pande Putu Januraga,M.Kes DrPH, dr Ketut Suarjana, MPH, Department of Public Health, Udayana University and Health Science Institute of Medika Persada Bali 


\section{REFERENCES}

[1] B. Aryanto, "Faktor-faktor yang berhubungan dengan kecenderungan turnover perawat di Rumah Sakit Islam 'Ibnu Sina' Yarsi Sumbar Bukittinggi,” Ners J. keperawatan, vol. 7, no. 2, pp. 156-160, 2011.

[2] P. S. Tobing, "Pengaruh karakteristik perawat dan lingkungan kerja terhadap keinginan pindah kerja (intention turnover) perawat di rumah sakit swasta di Kota Medan tahun 2009," Universitas sumatra utara, 2009.

[3] R. E. Langitan, "Faktor-faktor yang mempengaruhi kejadian turnover perawat pelaksana tahun 2009 di Rumah Sakit Bhakti Yudha Depok [thesis]," Universitas Indonesia, 2010.

[4] Alfiyah, "Faktor-faktor yang berhubungan dengan turnover intention perawat di Brawijaya Women and Children Hospital Jakarta tahun 2013.” 2013.

[5] L. Rachman and A. Dewanto, "Pengaruh employee engagement terhadap kepuasan kerja dan turnover intention perawat (studi pada Rumah Sakit Wava Husada Kepanjen Malang )," J. Apl. Manaj., vol. 14, no. 2, pp. 322-333, 2016.

[6] I. Mardiana, "Hubungan kepuasan kerja dengan turnover intentions pada perawat Rumah Sakit Dhuafa," vol. 9, no. 2, pp. 119-130, 2014.

[7] L. Agustina, "Pengaruh work-family conflict terhadap job satisfaction dan turnover intention pada profesi akuntan publik (studi empiris pada Kantor Akuntan Publik di DKI Jakarta \& Bandung)," J. Ilm. Akunt., vol. 7, no. 2, pp. 100 $116,2008$.

[8] A. M. Mosadeghrad, "Occupational stress and turnover intention: implications for nursing management," Int. J. Heal. policy Manag., vol. 1, no. 2 , pp. 169-176, 2013.

[9] F. Novliadi, "Intensi turnover karyawan ditinjau dari budaya perusahaan dan kepuasan kerja [thesis]," Universitas Sumatera Utara, 2007.

[10] A. Kistyanto, "Pengaruh Spiritualitas di Tempat Kerja Terhadap Turnover Intention Melalui Komitmen Organisasi," J. Manaj. Fak. Ekon., 2013.

[11] I. A. Ridlo, Turn Over Karyawan " Kajian Literatur." Surabaya: Public Health Movement, 2012.
[12] Wibowo, Manajemen kinerja edisi kelima. Jakarta: PT. Raja Grafindo Persada, 2016.

[13] F. Luthans, Perilaku organisasi edisi kesepuluh. Yogyakarta, 2006.

[14] F. El-Jardali, H. Dimassi, N. Dumit, D. Jamal, and G. Mouro, "A national cross-sectional study on nurses intent to leave and job satisfaction in Lebanon: implications for policy and practice," BMC Nurs., vol. 8, no. 3, pp. 1-13, 2009.

[15] M. Elizabeth, "Hubungan antara pelanggaran kontrak psikologis menurut perawat dengan intention to quit dan kepuasan kerja perawat Rumah Sakit X tahun 2011 [thesis]," Universitas Indonesia, 2012.

[16] Haryati, "Turn over tenaga perawat di Rumah Sakit Harapan Bunda Batam [thesis]," Universitas Gadjah Mada, 2007.

[17] I. P. I. Prihanjana, "Rekomendasi menurunkan turnover rate karyawan menggunakan analisis faktor pendorong dan penarik," J. Adm. Kebijak. Kesehat., vol. 11, no. 1, pp. 38-43, 2013.

[18] P. E. Spector, "American Journal of Community Psychology," Am. J. Of Community Psychol., vol. 13, no. 6, 1985.

[19] Munandar, Psikologi Industri dan Organisasi. Jakarta: Universitas Indonesia, 2001.

[20] L. Lum, "Explaining nursing turnover intent: job satisfaction, pay satisfaction, or organizational commitment," J. Organ. Behav., vol. 19, no. 3, pp. 305-320, May 1998.

[21] R. Q. Danish, "Impact of reward and recognition on job satisfaction and motivation: an empirical study from Pakistan," Int. J. Bus. Manag., vol. 5, no. 2001, pp. 159-167, 2010.

[22] R. Andini, "Analisis pengaruh kepuasan gaji, kepuasan kerja, komitmen organisasional terhadap turnover intention [thesis]," Universitas Diponegoro, 2006.

[23] H. Handoko, Manajemen Sumber Daya Manusia. Yogyakarta: BPFE-UGM, 2000.

[24] Ministry of Health, "Regulation of the Republic of Indonesia Health Minister no. 40 of 2017 concerning the development of a clinical nurse's professional career path." 2017.

[25] S. Siagian, Manajemen sumber daya manusia. Jakarta: PT. Bumi Aksara, 2016. 